\title{
Ecological organization and succession during natural recolonization of a tropical pond
}

\author{
Daniel Guiral*, Robert Arfi, Marc Bouvy, Marc Pagano \& Lucien Saint-Jean \\ Centre de Recherches Océanologiques, ORSTOM, BP VI8, Abidjan, Côte d'Ivoire; * Laboratoire d'Hydrologie et \\ d'Océanographie Tropicale, Centre ORSTOM de Montpellier, 911 avenue Agropolis, 34032 Montpellier, France
}

Received 7 October 1992; in revised form 18 January 1994; accepted 26 January 1994

Key words: bacteria, phytoplankton, protozoa, rotifera, cyclopoids, succession, recolonization, tropical pond

\begin{abstract}
The structure of a planktonic community was studied in April 1990 for 24 days (D1 to D24) during the natural recolonization of a tropical pond (Côte d'Ivoire) made azoic by emptying and liming (D0). Abundances of bacterioplankton, phytoplankton, protozoans and zooplankton were studied twice daily, whereas hydrological descriptors (temperature, conductivity, oxygen, $\mathrm{pH}$, dissolved nutrients, sestonic weights) were recorded several times daily. After the pond treatment, the natural refilling from groundwater began immediately. The microheterotrophic (bacteria, flagellates, ciliates), phytoplanktonic (Coelastrum microsporum) and zooplanktonic (the rotifers Brachionus plicatilis and Hexarthra intermedia) communities were first based on opportunist species favored by the initially large nutritive availability. This close link with the trophic resources induced their rapid elimination, as soon as the food source was depleted by overconsumption. Due to liming effects, great amounts of degradable organic compounds allowed bacterial communities to develop before phytoplankton. This biological succession was first based on a catastrophic-type system, successively controlled by bottom-up factors (proliferation) and top-down factors (species collapse). Then, the colonization was completed with the development of secondary consumers (last stages of Apocyclops panamensis and chironomids). The progressive complexity of the system ensured the attenuation of the disturbing events. Finally, due to volume variations of the pond along the recolonization steps, the effects of the dilution process on bacteria and chlorophyll biomass were studied. In a context of non-limiting nutrient substrata, the microbial community was able to colonize the new volume within a few hours. Phytoplankton showed a more complex adaptation to the volume increase, with mixed effects of grazing, sedimentation and diurnal productions.
\end{abstract}

\section{Introduction}

The hierarchical organization of a food web is complex, being based on trophic level interrelations and on controls (top-down or bottom-up factors) of the various communities. This regulation is expressed through competition for space and trophic resources, and through selection of demographic strategies which allow biotope colonization and species perennity. Therefore, any ecological analysis implies to integrate the simple static description of an ecosystem structure in a dynamic context, including the system history.

Aquatic food web studies can be accomplished through several non-exclusive approaches. It is possible to compare ecosystems in order to relate their organization levels to the external conditions by which they are influenced. This analytical approach is often difficult to achieve and can be biased since differences can result from intrinsic organization factors that are not directly perceptible. Another way is to manipulate conditions in natural environments or in controlled mesocosms. These modifications produce less complex systems, thus permitting a better understanding of relationships existing between trophic levels (Keller \& Riebesel, 1989; Smith \& Hollibaugh, 1989). However, the organization rules of these simplified environments give only partial information on natural ecosystems. One can also use the temporary desynchronization observed during the natural colonization of an initially azoic environment, showing an

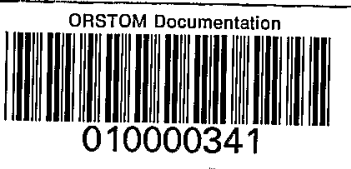


extremely low organization level (Connell \& Stayler, 1977; McCormick et al., 1991). This approach is based on the study of structuration steps, which are characterized by a succession of blooming and decaying phases. These pioneer and poorly diversified communities are regulated by endogenous factors (corresponding to the dissemination ability of species) amplifying the effects of even minimal changes in environmental conditions. This unicity of system transformation corresponds to a variability in the specific composition of communities, in which the various species assuming identical functions are forming guilds (Adams, 1985). These unstable phases precede a complexity of food webs, and a relative biomass stabilization.

In tropical environments, and in favorable trophic conditions, the climate can induce an acceleration of community successions, particularly during pioneer stages. In Layo ponds (Ebrié lagoon, Côte d'Ivoire) used for fish breeding (Hem et al., 1994), several studies have shown the main steps of the structuration of a system made azoic by emptying and liming (Legendre et al., 1987; Arfi et al., 1991). From a high initial nutrient stock, exuberant phytoplanktonic blooms are followed within a few days by large zooplanktonic developments. This general pattern is observed for each colonization with high variability in abundance and species composition, as well as in the periodicity of their development (Bonou, 1990).

Unfortunately, these previous works have neither described the processes of community changes with sufficient accuracy nor explained why these phenomena showed such high variability. This was essentially due to (1) a sampling frequency unadapted to the speed of successions and biochemical processes and (2) an insufficient number of ecological descriptors. A sampling strategy overcoming these inadequacies was designed to enable a better understanding of pond colonization during a study conducted in April 1990. The biological consequences of progressive (gradual filling of the pond from groundwater) or sudden (rain event) increases in water volume of the pond (therefore colonizable space) were also analyzed.

\section{Materials and methods}

The study was conducted from April 3 (D1) to 26 (D24) 1990 in a pond of the Layo aquaculture station on the Ebrié lagoon (Côte d'Ivoire; $5^{\circ} \mathrm{N}, 5^{\circ} \mathrm{W}$ ). The pond was completely drained off and limed $(0.2 \mathrm{~kg}$ $\mathrm{CaCO}_{3} \mathrm{~m}^{-2}$ ) on the afternoon of April 2 (D0). At the beginning of the survey, the wet surface and the pond volume were estimated to $425 \mathrm{~m}^{2}$ and $20.5 \mathrm{~m}^{3}$, respectively.

\section{Hydrology}

The pond volume $\left(V_{i}, \mathrm{~m}^{3}\right)$ was estimated twice daily from measurements of the wet surface corresponding to the water height $\left(H_{i}, \mathrm{~m}\right)$. The evaporation was estimated daily in a flat tank (surface: $1 \mathrm{~m}^{2}$ ) placed in the pond and extrapolated $\left(E_{i}, \mathrm{~m}^{3}\right)$ to the wet surface. Input from precipitation was measured on a daily basis using a rain gauge placed on a pond bank and extrapolated $\left(P_{i}, \mathrm{~m}^{3}\right)$ to the cumulated surface $\left(816 \mathrm{~m}^{2}\right)$ of the pond and its drainage area. These data were used to estimate the input from the ground water:

$$
N_{i}=\left(V_{i+1}-V_{i}\right)+E_{i}-P_{i}
$$

\section{Sampling strategy}

The number of samples collected varied according to the descriptors:

- six values per hour at $10 \mathrm{~cm}$ below the surface were recorded for temperature and dissolved oxygen;

- six samples per day (at 2, 6,10 am and 2,6,10 pm) at $10 \mathrm{~cm}$ below the water surface were taken for conductivity, $\mathrm{pH}$ and dissolved nutrients measurements;

- twice daily (at 8 am and $6 \mathrm{pm}$ ), the whole water column was sampled for microbial and phytoplankton analyses (integrated samples using a peristaltic pump) and the water was filtered through a $63 \mu \mathrm{m}$ screen at the pump outlet;

- twice daily (at 10 am and $10 \mathrm{pm}$ ), the zooplankton was sampled ('Chinese hat' $63 \mu \mathrm{m}$ nets, $40 \mathrm{~cm}$ aperture, $5 \mathrm{~cm}$ height). Three nets were laid on the bottom and hauled $15 \mathrm{~min}$ later. The $3 \mathrm{sam}$ ples were pooled, and buffered formalin ( $4 \%$ final concentration) was added for preservation;

- once daily (11 am), the sediment was sampled (manual PVC corers, $3.6 \mathrm{~cm}$ diameter for meiofauna, $7 \mathrm{~cm}$ diameter for macrofauna) and buffered formalin was added to the uppermost $5 \mathrm{~cm}$ of each core for preservation.

The groundwater was sampled every three days using a piezometer located $40 \mathrm{~m}$ north of the pond. The atmospheric water was sampled in the rain gauge reservoir. Conductivity, $\mathrm{pH}$ and nutrient concentrations were measured on these samples. 
Physical, chemical and biological descriptors

Temperature (Thermistor), dissolved oxygen (YSI 58 oxygen-meter), conductivity (Taccussel conductimeter) and $\mathrm{pH}$ (Methrom $\mathrm{pH}$-meter) data were measured immediately or within a few hours after sampling. Dissolved nutrient concentrations $\left(\mathrm{NO}_{2}-\mathrm{N}, \mathrm{NO}_{3}-\mathrm{N}\right.$, $\mathrm{NH}_{4}-\mathrm{N}, \mathrm{PO}_{4}-\mathrm{P}$ ) were measured using an AutoAnalyser (Strickland \& Parsons, 1972). Proportions of ionized and gaseous forms of ammonia were calculated from the formula proposed by Aminot \& Chaussepied (1983).

Bacteria direct counts were determined using an epifluorescence microscopy procedure (Porter \& Feig, 1980). Mean bacterial volumes (up to 100 cells) were calculated from measurements on photographic slides. The carbon biomass was estimated assuming a conversion factor of $0.12 \mathrm{pg} \mathrm{C} \mu \mathrm{m}^{-3}$ for cell size $>0.2 \mu \mathrm{m}^{3}$ (Nagata \& Watanabe, 1990) and $0.20 \mathrm{pg} \mathrm{C} \mu \mathrm{m}^{-3}$ for cell size $<0.2 \mu \mathrm{m}^{3}$ (Simon \& Azam, 1989). Heterotrophic nanoflagellates (glutaraldehyde-preserved samples) were enumerated on Nuclepore filters ( $1 \mu \mathrm{m}$ pore size) with epifluorescence microscopy after DAPI staining (Sherr \& Sherr, 1987). Mean biovolumes were also calculated from measurements on photographic slides and the carbon biomass calculated from a conversion factor $\left(0.20 \mathrm{pg} \mathrm{C} \mu \mathrm{m}^{-3}\right.$, Borsheim \& Bratbak, 1987). Glutaraldehyde-preserved ciliates were enumerated using an inverted microscope (Utermöhl, 1958). Volumes were calculated from the measurements of linear dimensions and converted into carbon biomass using a factor of $0.12 \mathrm{pg} \mathrm{C} \mu \mathrm{m}^{-3}$ (Turley et al., 1986).

Identification and enumeration of phytoplankton cells (Lugol preserved samples) were conducted using an inverted microscope (Utermöhl technique). Chlorophyll $a$ concentrations (corrected from phaeopigments) were determined fluorometrically after size fractionation ( $<3 \mu \mathrm{m}, 3-12 \mu \mathrm{m}$ and $12-63 \mu \mathrm{m}$ ) on Nuclepore membranes and methanol extraction (Yentsch \& Menzel, 1963).

Zooplankton organisms were identified to species and stages on fixed material and counted on total samples or sub-samples in order to obtain at least 100 individuals per category.

Benthic animals were counted directly (macrofauna $>1 \mathrm{~mm}$ ) or after filtration through a $0.04 \mathrm{~mm}$ mesh sieve (meiofauna $<1 \mathrm{~mm}$ ). All meiofauna specimens were extracted by density separation with colloidal silica Ludox (De Jonge \& Bowman 1977).

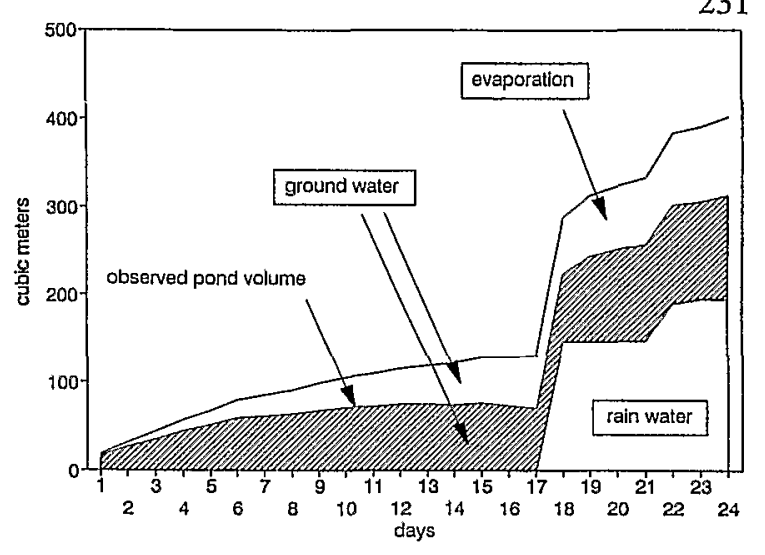

Fig. 1. Daily variations of the pond volume estimated from the inputs (groundwater and rain) and the output (evaporation).

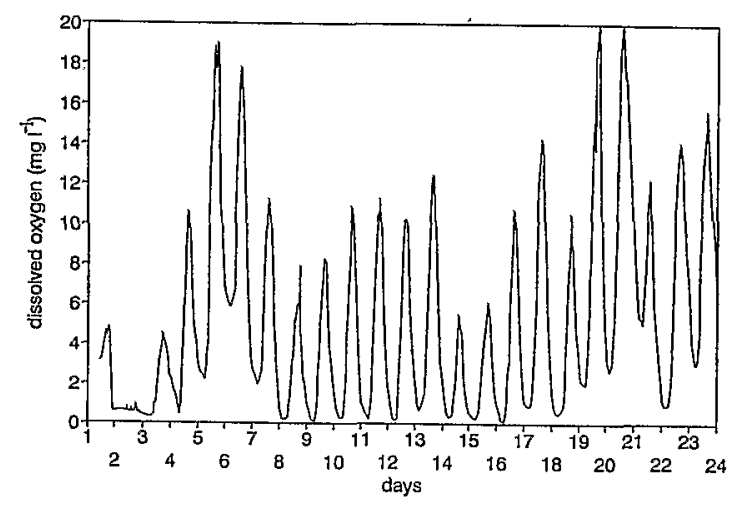

Fig. 2. Time series of dissolved oxygen of the pond water.

\section{Results}

\section{Pond volume and conductivity}

Once drained out, cleaned and limed (D0), the pond refilling occurred naturally from groundwater. Three steps were defined (Fig. 1):

- a slow and regular increase of the water level (D1D6),

- a volume stabilization (D7-D17), corresponding to a decrease of groundwater input and an increase of evaporation rates. At the end of this period, a decrease of the pond volume was observed, reflecting an evaporation process more important than the water input;

- a rapid volume increase, after the rain which occurred during D17-D18 night $(180 \mathrm{~mm})$, D21 afternoon (52 $\mathrm{mm}$ ) and D23 morning (6 mm).

Before the first storm, the pond volume was equal to $92 \mathrm{~m}^{3}$. It increased to $246 \mathrm{~m}^{3}$ after the first rain and to $325 \mathrm{~m}^{3}$ after the second one. At the end of the study, 
the volume was equal to $335 \mathrm{~m}^{3}$. Between D1 and D17, conductivity increased from 8.82 to $11.97 \mathrm{mS} \mathrm{cm}^{-1}$ as a consequence of intense evaporation. After the first storm, conductivity decreased to $5.87 \mathrm{mS} \mathrm{cm}^{-1}$, and was equal to $7.11 \mathrm{mS} \mathrm{cm}^{-1}$ at the end of the survey.

\section{Temperature, $p H$ and dissolved oxygen}

These variables showed large diel variations. Daily temperatures ranged from $26{ }^{\circ} \mathrm{C}$ to $34^{\circ} \mathrm{C}$, with minima observed around 6-7 am and maxima around 2$3 \mathrm{pm}$. When the sky was cloudy, high values were under $30^{\circ} \mathrm{C}$. Precipitation induced water cooling $\left(24^{\circ}\right.$ C, D17-D18 night). After alkalinization due to lime spreading, $\mathrm{pH}$ values ranged from 7.0 to 8.5 . The large diel variability (minima at $2 \mathrm{am}$, maxima at $2 \mathrm{pm}$, amplitude $1.5 \mathrm{pH}$ unit) was inscribed within an alkalinization trend. A few hours after liming, dissolved oxygen values were close to $5 \mathrm{mg} 1^{-1}$ in the residual pool of water (Fig. 2). A $36 \mathrm{~h}$ anoxia period began 2 days after liming; afterwards, oxygen concentrations showed obvious diel variations. The lowest values (often close to 0 ) were observed early in the morning (around $6 \mathrm{am}$ ), the highest in the afternoon (around $4 \mathrm{pm}$ ). Two sequences (D5-D7 and D19-D21) with high oxygen maxima ( $>16 \mathrm{mg} \mathrm{l}^{-1}$ ) and minima (4$6 \mathrm{mg} \mathrm{l}^{-1}$ ) framed a period (D8-D18) characterized by low values close to 0 and high values never greater than $12 \mathrm{mg} \mathrm{l}^{-1}$.

\section{Nutrients}

Ammonia was the dominant form of dissolved mineral nitrogen (Fig. 3a). From D1 to D4, concentrations increased rapidly and peaked at $412 \mu \mathrm{M}^{-1}$. This increase corresponded to an eventual recovery of ammonification processes and to the input of sediment pore water under groundwater pressure. This step was followed by a decrease in concentrations, leading to a temporary depletion on D6. Until the end of the survey, ammonia values fluctuated with a marked diel rhythm and minimal values were noted in the late afternoons. Owing to the large amplitude of temperature and $\mathrm{pH}$ values and to their diel fluctuations, proportion of ammonia under ionized and gaseous forms showed large variations. At the beginning of the study, the high increase in $\mathrm{pH}$ due to liming induced the change from the ionized $\left(\mathrm{NH}_{4}-\mathrm{N}\right)$ to the gaseous $\left(\mathrm{NH}_{3}-\mathrm{N}\right)$ form of most of the ammonia present in the pond water. Accumulation of the ionized form began actually 36 hours after lime spreading, when less alkaline $\mathrm{pH}$ conditions occurred. Afterwards, $\mathrm{NH}_{3}-\mathrm{N}$ and $\mathrm{NH}_{4}-\mathrm{N}$ concentrations showed an opposite diel rhythm. However, $\mathrm{NH}_{3}$ $\mathrm{N}$ values increased with the progressive alkalinization of the pond water. At the end of the study, the $\mathrm{NH}_{3}$ -N diurnal concentrations represented 20 to $40 \%$ of the total ammonia between 6 am and $10 \mathrm{am}$, and 60 to $80 \%$ between $2 \mathrm{pm}$ and $6 \mathrm{pm}$.

Between D1 and D17, oxidized forms of nitrogen showed low concentrations (nitrate and nitrite levels under $2 \mu \mathrm{M}^{-1}$ and $0.3 \mu \mathrm{M}^{-1}$ respectively, Fig. 3b). After the first storm, rain water characterized by high nitrate concentrations (Table 1) induced a sharp increase of that compound in the pond water. Highest values for nitrate $\left(20.1 \mu \mathrm{M} \mathrm{l}^{-1}\right)$ and nitrite $\left(2.2 \mu \mathrm{M} \mathrm{l}^{-1}\right)$ were immediately observed after the first rain. They were followed by a gradual decrease up to D24. Orthophosphate concentrations never exceeded $2.2 \mu \mathrm{M} \mathrm{l}^{-1}$, in accordance with the low $\mathrm{PO}_{4}-\mathrm{P}$ load of the input waters (Table 1). After a short sequence of high values following the lime spreading (up to $\left.1.3 \mu \mathrm{M} \mathrm{1}^{-1}\right), \mathrm{PO}_{4}-\mathrm{P}$ concentrations remained close to $0.1 \mu \mathrm{M} \mathrm{l}^{-1}$ until D8; then, they significantly increased (2.2 $\mu \mathrm{M} \mathrm{1}^{-1}$ ) from $\mathrm{D} 9$. Afterwards, diel variations were observed (Fig. 3c), with nocturnal maxima 3 to 4 times higher than diurnal minima. From D18, these diel fluctuations were attenuated with a sharp decrease of maximum values, and the concentrations remained close to $0.5 \mu \mathrm{M} \mathrm{l}^{-1}$.

Considering the nutrient concentrations in groundwater and rainwater (Table 1), it appeared that ammonia entered the pond mainly from groundwater, and nitrate from precipitations, directly (the rain) and indirectly (from groundwater). Ortho-phosphates, not abundant in the water inputs, had a sedimentary origin. Their availability corresponded to the desorption of forms adsorbed on clay due to the chemical conditions induced by the pond treatment (emptying and liming), and to the mineralization of organic detritus, once favorable conditions to catabolic activities were reached. Nutrient concentrations in the pond depended therefore on the equilibrium between the various inputs and the biological immobilization.

\section{Bacterioplankton}

Twenty four hours after lime spreading, the bacterial biomass was low in the pond water $\left(0.03 \mu \mathrm{g} \mathrm{C} \mathrm{m}^{-1}\right.$, D1). Cell densities were low $\left(0.6 \times 10^{6} \mathrm{cell} \mathrm{m}^{-1}\right)$, but the bacteria showed large biovolumes (average: $0.417 \mu \mathrm{m}^{3}$ ). Then, bacterial abundances increased, reaching a maximum of $42.5 \times 10^{6} \mathrm{cell} \mathrm{ml}^{-1}$ (D4). The 

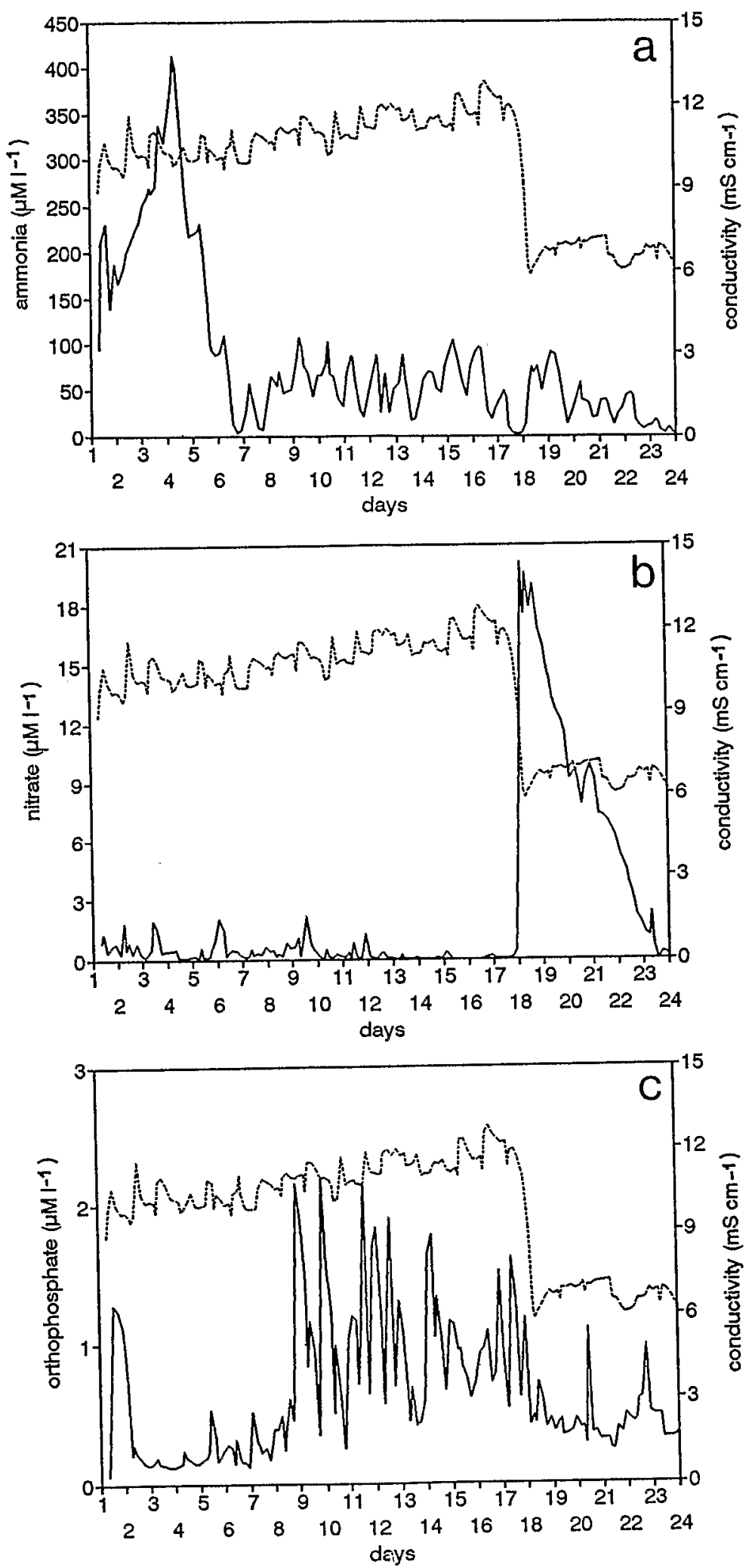

Fig. 3. Daily variations in ammonia (a), nitrate (b) and phosphate (c) concentrations (dashed line: conductivity of the pond water). 
Table 1. Chemical characteristics (conductivity and nutrients) of ground and rain water during the study.

\begin{tabular}{llllll}
\hline & $\begin{array}{l}\text { Conductivity } \\
\left(\mathrm{mS} \mathrm{cm}^{-1}\right)\end{array}$ & $\begin{array}{l}\mathrm{NO}_{2}-\mathrm{N} \\
\left(\mu \mathrm{M}^{-1}\right)\end{array}$ & $\begin{array}{l}\mathrm{NO}_{3}-\mathrm{N} \\
\left(\mu \mathrm{M} \mathrm{I}^{-1}\right)\end{array}$ & $\begin{array}{l}\mathrm{NH}_{4}-\mathrm{N} \\
\left(\mu \mathrm{M} \mathrm{I}^{-1}\right)\end{array}$ & $\begin{array}{l}\mathrm{PO}_{4}-\mathrm{P} \\
\left(\mu \mathrm{M} \mathrm{I}^{-1}\right)\end{array}$ \\
\hline groundwater & & & & & \\
D1 to D17 & 9.86 & 0.6 & 0.2 & 294 & 0.7 \\
D18 to D20 & 5.05 & 0.9 & 2.5 & 177 & 1.5 \\
D21 to D24 & 4.73 & 7.9 & 46.8 & 116 & 0.8 \\
rainwater & & & & & \\
D17-D18 & 0.15 & 1.1 & 18.1 & 38.4 & 1.2 \\
D20 & 0.05 & 0.2 & 2.6 & 9.7 & 0.3 \\
D23 & 0.04 & 0.3 & 10.9 & 8.8 & 0.2 \\
\hline
\end{tabular}

highest biomass $\left(1.25 \mu \mathrm{g} \mathrm{C} \mathrm{ml}^{-1}\right)$ was observed on $\mathrm{D} 3$ (Fig. 4). During this sequence, the percentage of fixed bacteria increased in number (D1: $28 \%, \mathrm{D} 4: 50 \%$ ) as well as in biomass (respectively $32 \%$ and $41 \%$ ). This development was followed by a sharp decrease of densities ( $11.3 \times 10^{6} \mathrm{cell} \mathrm{m}^{-1}$, D5 morning), inducing a lower biomass $\left(0.33 \mu \mathrm{g} \mathrm{C} \mathrm{ml}^{-1}\right)$. Afterwards, the average biovolumes and abundances remained stable without obvious diel cycle (biomass ranging from 0.15 to $0.50 \mu \mathrm{g} \mathrm{C} \mathrm{ml}^{-1}$ ).

\section{Protozoa}

Heterotrophic nanoflagellates (average cell biovolume: $\left.2.2 \mu \mathrm{m}^{3}\right)$ first appeared on $\mathrm{D} 2$, and peaked on $\mathrm{D} 3\left(0.13 \mu \mathrm{g} \mathrm{C} \mathrm{ml}^{-1}\right.$, Fig. 4). Their biomass decreased sharply from D6, and remained low and steady until D13. A second development characterized by a high variability was then observed with a maximum biomass close to $0.06 \mu \mathrm{g} \mathrm{C} \mathrm{ml}^{-1}$. Ciliates (essentially non-loricate oligotrichs from the genera Strombidium and Strombilidium) appeared on D3 (Fig. 4) and showed a maximum biomass on D7 $\left(0.86 \mu \mathrm{g} \mathrm{C} \mathrm{ml}^{-1}\right)$. This blooming sequence was followed by a decay, the abundances remaining very low after D16.

\section{Phytoplankton}

Two algal blooms were observed, the first between D4 and D7 and the second beginning on D16 (Fig. 5). The first was dominated by a colonial chlorophyte (Coelastrum microsporum), accompanied by cyanobacteria (Chroococcus dispersus, Romeria gracilis and Synechocystis sp.) and by other chlorophytes (Chlamy- domonas sp., Chlorella sp.). During the second development, Coenocystis reniformis, an other colonial chlorophyte was the first to bloom (D16-D17), followed after the first storm by $C$. microsporum (D19D24). Several species of the genus Scenedesmus (S. sooi, S. falcatus, S. opoliensis, S. arcuatus and $S$. smithii) accompanied the colonial chlorophytes. Between these two major blooms, a diatom (Chaetoceros whigami) was the dominant species, associated with cyanobacteria (Oscillatoria sp., Synecocystis sp.) and cryptophytes (Cryptomonas sp., Cyanomonas sp.).

Variations of the chlorophyll biomass closely followed those of the total algal biovolume. A significant increase corresponding to the first algal bloom was observed from D3 (Fig. 5) and culminated on D5 $\left(788 \mu \mathrm{g} \mathrm{l}^{-1}\right)$. Picoplanktonic cells $(<3 \mu \mathrm{m}$ mainly cyanobacteria) formed $21 \%$ of the total biomass, while larger algae (3-12 $\mu \mathrm{m}$, mainly C. microsporum) accounted for $51 \%$ of the total. A rapid decay of chlorophyll biomass (34 $\mu \mathrm{g}^{-1}$ on D9) followed this exponential bloom. Afterwards, the values fluctuated around $80 \mu \mathrm{g} \mathrm{1}^{-1}$, with cells of size comprised between 12 and $63 \mu \mathrm{m}$ representing the main part (63\%) of the biomass. During the second peak on D17 (384 $\mu \mathrm{g} \mathrm{l}^{-1}$ ), the largest part of that biomass corresponded to $3-12 \mu \mathrm{m}$ cells (size range of $C$. microsporum and $C$. reniformis cells) while picoplankton contributed only $9 \%$ of the total standing crop. During the storm sequence (D18-D21), concentrations remained high (average: $167 \mu \mathrm{g} \mathrm{l}^{-1}$ ). From this step, a marked diel cycle appeared, essentially based on cells $>12 \mu \mathrm{m}$ (Scenedesmus sp.). 

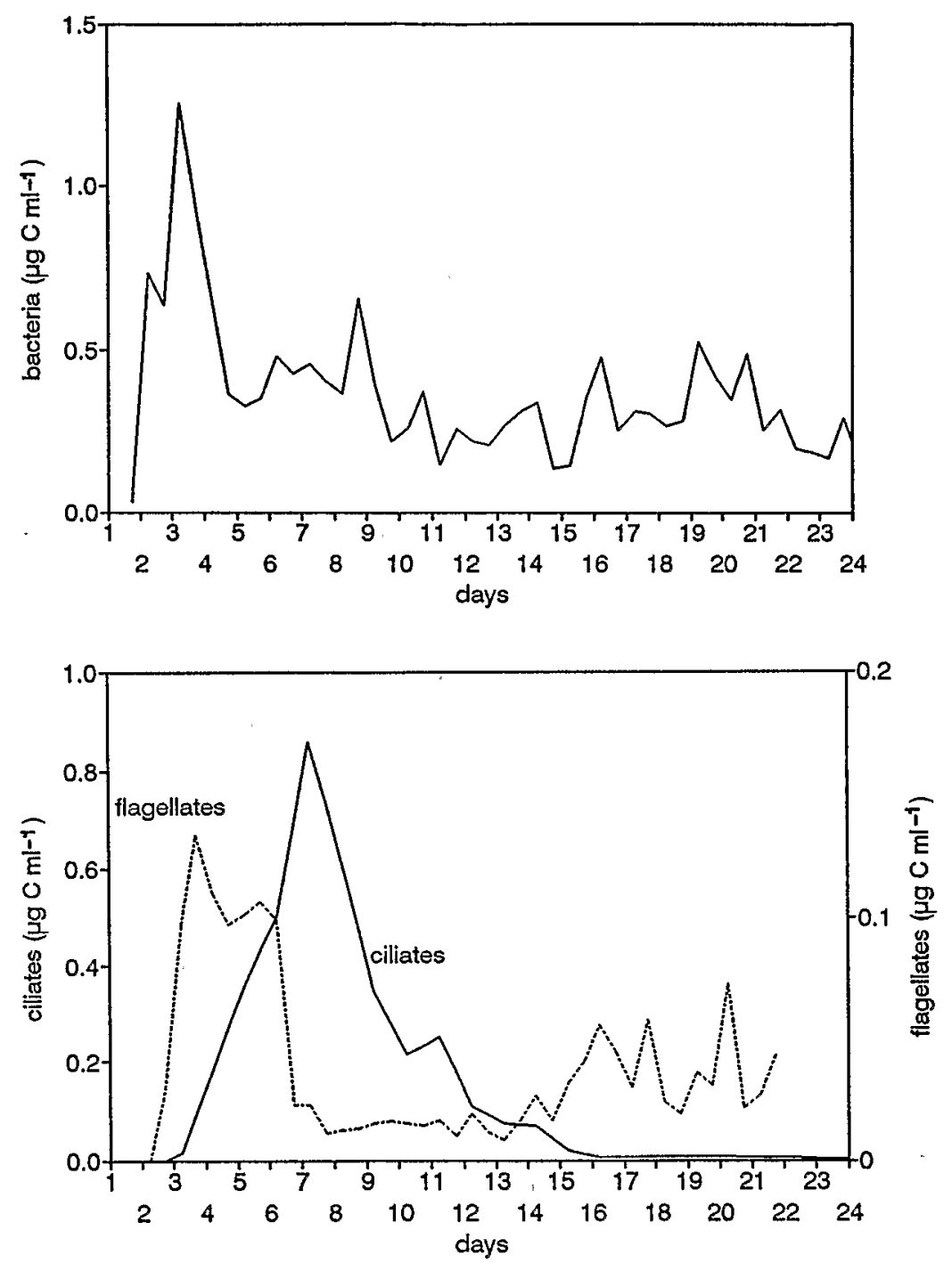

Fig. 4. Daily variations in bacterial biomass (a) and heterotrophic flagellates and ciliates biomasses (b).

\section{Zooplankton}

Very little zooplankton $\left(<1\right.$ ind. $\left.1^{-1}\right)$ was sampled in the pond before D5, and significant abundances were only observed after the first algal bloom. From D6, 3 species appeared, each of them showing an exponential development (Fig. 6):

- the rotifer Brachionus plicatilis peaked on D8 (59000 ind. $\mathrm{I}^{-1}$ ).

- the rotifer Hexarthra intermedia appeared when B. plicatilis showed maximal densities and peaked on D13 (35000 ind. $1^{-1}$ ).
- the copepod (Apocyclops panamensis) showed significant development from D7 and the total density (nauplii, copepodites and adults) increased progressively, reaching a maximum on D16 (5800 ind. $\left.1^{-1}\right)$.

While the abundance of the two rotifer species decreased rapidly (at about the same rate at which they grew), the copepod population maintained high densities until the end of the study. No diel variations of densities were observed for these three species probably because the sampling strategy (integrated sampling of the whole water column) avoided vertical migration effects. 

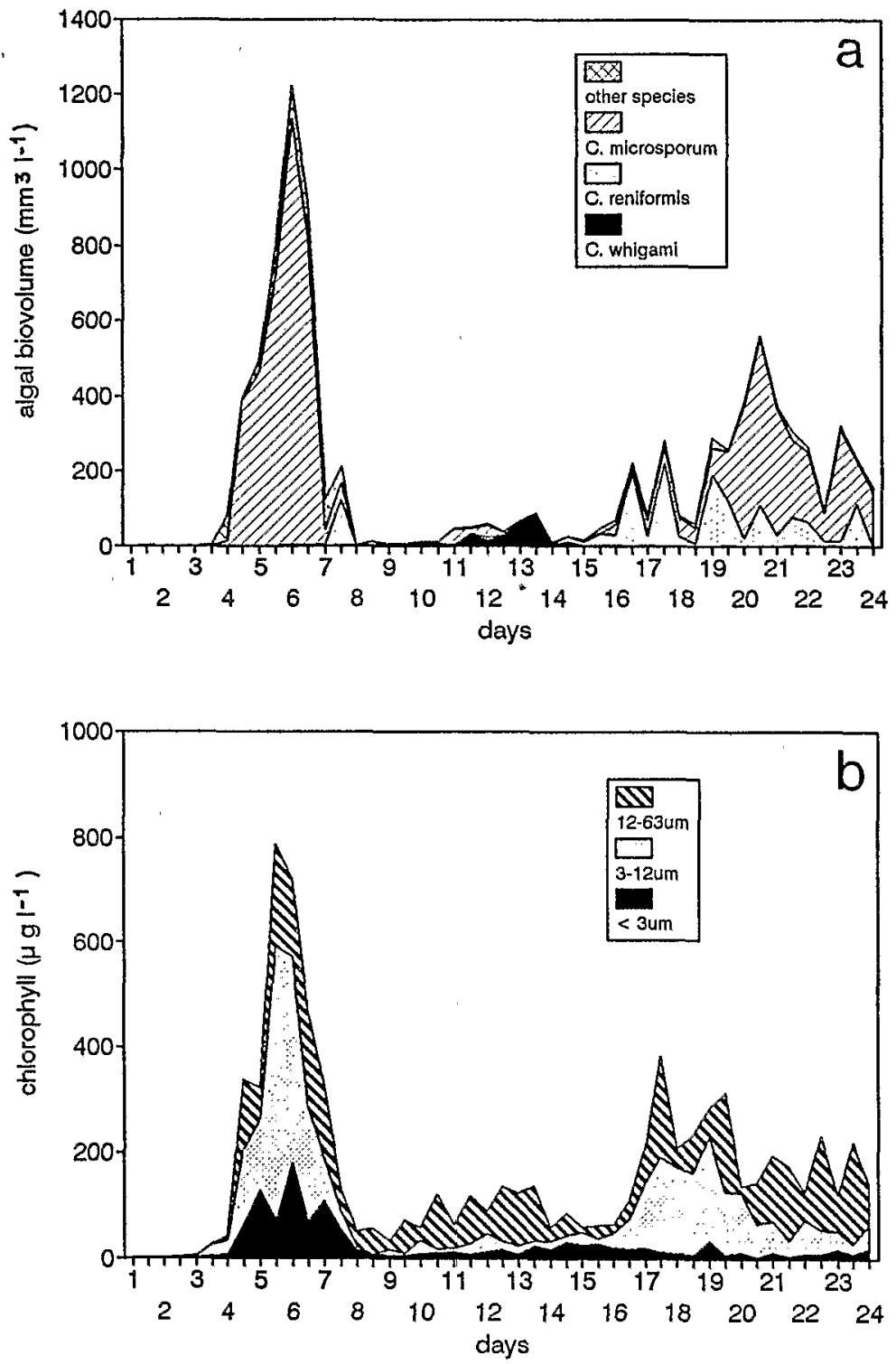

Fig. 5. Daily variations in algal biovolumes of the phytoplanktonic community (Chaetoceros whigami, Coenocystis reniformis, Coelastrum microsporum and other species) (a) and in chlorophyll concentrations (size fractionation) (b).

\section{Benthos}

Meiofauna organisms (nematodes, harpacticoid copepods, ostracods) appeared simultaneously, but were noticeably abundant from D7 (170 ind. $10 \mathrm{~cm}^{-2}$ ). After, the standing crop ranged from 250 to 650 ind. $10 \mathrm{~cm}^{-2}$. The macrofauna was mainly represented by a gastropod (Nemalia sp.), always observed with numbers ranging from 7 to 27 ind. $10 \mathrm{~cm}^{-2}$. Chironomid larvae were observed from D4 in the water column and at the water-sediment interface. Their maximum den- sities were observed on D17 in the water $\left(11\right.$ ind. $\left.1^{-1}\right)$ and on D20 in the sediment ( 3 ind. $10 \mathrm{~cm}^{-2}$ ).

\section{Discussion}

\section{Effects of liming}

Liming is commonly practiced in aquaculture, in order to accelerate organic matter decomposition in the sediments, to precipitate dissolved organic matter present 

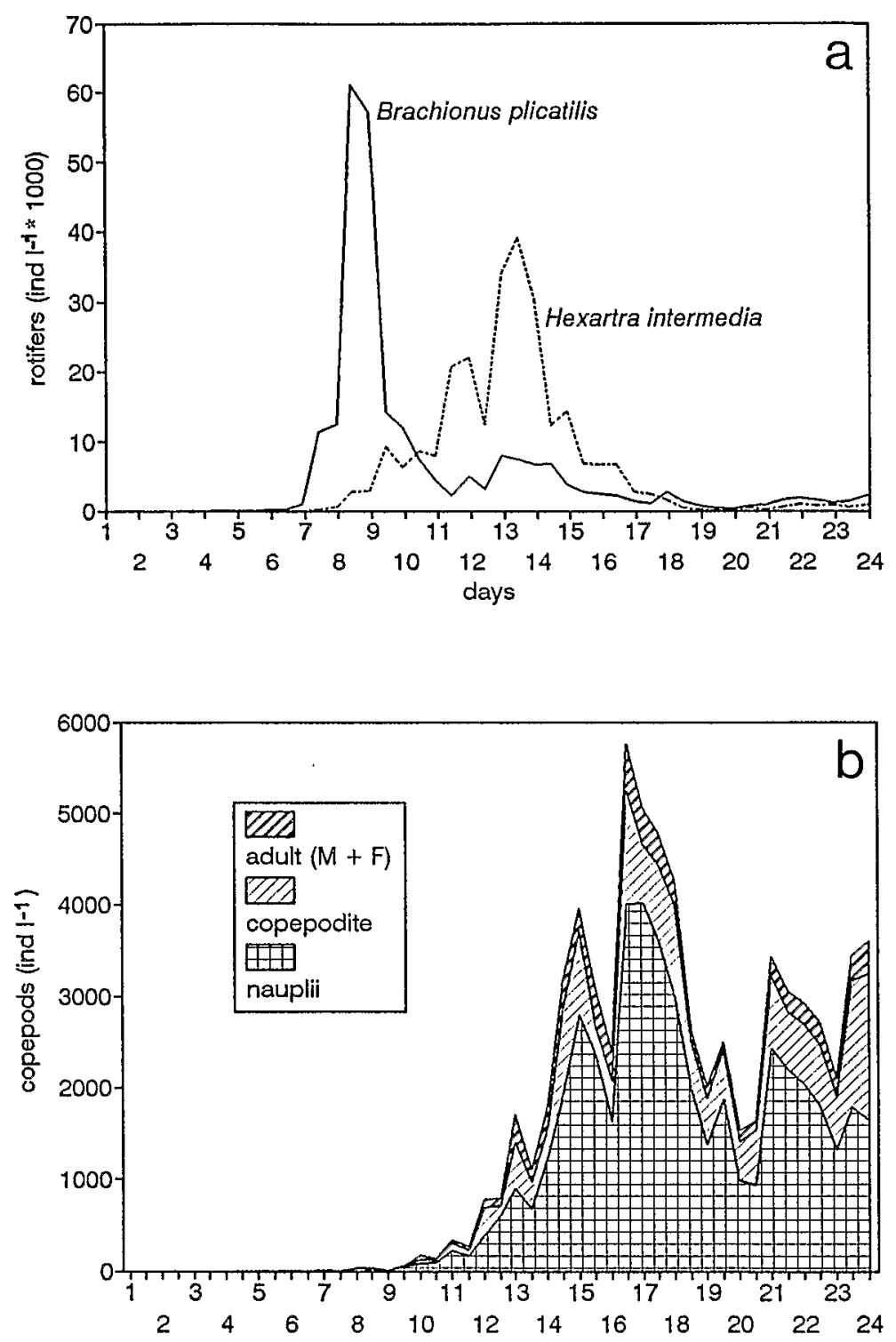

Fig. 6. Daily variations in densities of rotifer (a) and cyclopid copepods (Apocyclops sp.) (b). Abbreviations: $\mathrm{M}$ for male, $\mathrm{F}$ for female.

in the water column and to sterilize the ecosystem (Delincé, 1992). Effects of liming are numerous on water chemistry and on sediment $\mathrm{pH}$ and redox potential. Alkalinization induces a massive input of mineral $\mathrm{CO}_{2}$ and a chemical hydrolysis of the organic materi$\mathrm{al}$ in the water and in the superficial sediment (Arce \& Boyd, 1975; Hunt \& Boyd, 1981). During refilling by groundwater, the dissolved compounds present in pore water entered into the pond (piston effect). The pond, almost azoic, was then characterized by high concentrations of ammonia and of labile organic compounds. Then, the colonization process began in a particular context due to liming consequences: turbid and basic water rich in nutrients and dissolved organic compounds.

\section{Ecological successions}

The initial conditions described above and particularly the presence of easily degradable organic compounds were favorable for the development of a trophic system based on heterotrophy. Then, contrary to common succession patterns, the bacterial development preceeded the algal bloom, which usually provides available sub- 
strates for bacteria (like exudates, Riemann \& Sondergaard, 1984). This bacterial development was based on large cells, probably issued from the precedent community and which disappeared rapidly by sedimentation and/or lysis. Smaller cells produced a bacterial bloom culminating on D3. The lack of qualitative data did not allowed us to demonstrate an eventual link between these two communities which were only separated from morphological criteria (cell size). The activity of the heterotrophic communities induced a high oxygen demand, neither compensated by diffusion at the air-water interface nor by an autotrophic activity, nonexistent at this time. This situation induced the temporary anoxia observed during a $36 \mathrm{~h}$ period (D2-D3) in the pond water. Decrease in bacterial density may have resulted from the concurrent development of heterotrophic nanoflagellates, which are known to be able to control the bacterial biomass in several freshwater ecosystems (Sanders et al., 1989).

Due to liming effects, favorable conditions for phytoplankton (ammonia, pH decrease and light penetration) occurred after bacterial development. A phytoplanktonic community dominated by Coelastrum microsporum, a colonial chlorophyte, showed an exponential development from D3. Other algae (cyanobacteria, cryptophytes and other chlorophytes species) were non colonial small cells. This algal bloom rapidly reconstituted the oxygen stock and produced diurnal oxygen over-saturations. It was also probably responsible for the sharp decrease in ammonia concentration. During the bloom period, low values of orthophosphates were found in the pond water while high values were noted in superficial sediment. This phenomenon suggested a diffusive flux of $\mathrm{PO}_{4}-\mathrm{P}$ from the sediment toward the pond water, directly controlled by the biological demand. The decrease of the algal biomass limited the diurnal oxygen over-saturation and the oxygen stock was then more limited at the end of the photosynthesis period, inducing again nocturnal anoxia. During this decaying phase, the major regulation of the autotrophic biomass was carried out through grazing by upper trophic levels. Most of the control of these organisms was probably conducted through grazing by ciliates, able to ingest small seston particles (Beaver \& Crisman, 1989; Sherr et al., 1991) and later by the rotifer Brachionus plicatilis, able to eat particles within a large size range (Pourriot, 1977). The desynchronization existing between the maximum densities of flagellates, ciliates and rotifers (B. plicatilis) suggested that the heterotrophic flagellates were controlled through predation. This possible regulation by ciliates corroborates the previous works of Bernard \& Razzoulzadegan (1990), suggesting that oligotrich ciliates of the genera Strombidium are able to eat prey of sizes close to $2 \mu \mathrm{m}$. The decreasing biomass of picophytoplankton and flagellates induced the progressive disappearance of ciliates. The decrease of Brachionus densities probably had a similar origin (bottom-up control). But for this species, the initial trophic-based control induced an autoregulation by the modification of their reproductive process. This led to a large decrease in their fecundity, since the parthenogenetic mode was replaced by a sexual reproduction mechanism, which was characterized by production of resting eggs with time differed hatching.

From $\mathrm{D} 8$ to $\mathrm{D} 11$, the environmental conditions were characterized by a trend to $\mathrm{PO}_{4}-\mathrm{P}$ accumulation in water, a partial reconstitution of the ammonia standing stock and by significantly lower oxygen maxima. The phytoplanktonic biomass was very low and still dominated by chlorophytes (clear-water phase). The zooplankton community was based on two species at the beginning of their growth sequence, the rotifer Hexarthra intermedia and the copepod Apocyclops panamensis. The biomass increase of $H$. intermedia was lower than that of $B$. plicatilis. This lower development may have resulted from a slower intrinsic growth rate but also from significant densities of potential predators (adults of Apocyclops, chironomid larvae) and/or from the relatively low trophic resources. Indeed, when $H$. intermedia reached its maximum biomass, the microheterotrophic organisms showed a low abundance and the phytoplankton was essentially represented by the nanoplanktonic diatom Chaetoceros whigami.

The adults and last copepodite stages of $A$. panamensis were present in the pond at the beginning of the study, and this phenomenon could be explained by the release of dormancy of the last copepodite stages (C4C5) or by a simple recruitment of individuals which had resisted the liming. However, the population increased significantly only from $\mathrm{D} 9$. This development was probably permitted by the first rotifer bloom which provided prey for adults and stages $\mathrm{C} 4-\mathrm{C} 5$, known to be carnivorous (their direct ingestion of B. plicatilis was verified experimentally in this study). High fecundity rates were then observed and were enhanced during the bloom of $H$. intermedia. The biomass increase of Apocyclops was slower than that of rotifers, which could be explained by its slower intrinsic growth rate.

The second algal bloom based essentially on C. reniformis began on $\mathrm{D} 16$, simultaneously with the 
decrease of rotifera biomass and could then be related to the decrease in grazing pressure.

The first storm caused a doubling of the pond volume along with changes in physical and chemical water characteristics (decrease of conductivity, nitrogen nutrient input, in particular nitrate). These new conditions induced another proliferation of Coelastrum microsporum, and the development of several species of Scenedesmus. This phenomenon can be defined as new space utilization by organisms from an already structurated ecosystem. It was characterized by the development of other species, substituted or added to those already present in the pond. The relatively slow growth rates of these species excluded bloomlike sequences of development comparable to those observed during the pioneer phase. Moreover, predation by carnivorous organisms (copepods and chironomids) allowed diversification of the food web in the pond. This stabilization and diversification of the heterotrophic communities contrasted sharply with the persistence of a non-diversified autotrophic community, featuring large fluctuations until the end of the study.

In conclusion, the colonization appeared as rapidly completed within 3 weeks. This may be related to the vicinity of other ponds featuring different steps of ecological maturity and which may have constituted a reservoir for all species. The timing in biological group developments would then only depend on (1) their intrinsic growth ability, (2) favorable physical and chemical conditions and (3) the availability of appropriate trophic resources. This colonization scheme, which requires the necessary transformation of the environment by a community previously established, agrees with the concepts developed by Clément (1916) and recently discussed by Mc Cormick et al. (1991). For these authors, communities are predominant over populations in succession dynamics, and particularly in the case of colonization of virgin and non-isolated environments. Moreover, the large diel variations observed in the pond for some hydrological (like oxygen, Fig. 3) and biological descriptors seemed unlikely to influence significantly the nature and the rhythm of successions. Each proliferation stage was thus consecutive to drastic environmental changes (physical, chemical as well as trophic factors). Once these random disturbing events were integrated by a system very sensitive to the initial conditions, a logical and determinist succession of events could take place and develop until a new perturbation. After, the progressive complexity of the system will attenuate the sensitivity to random perturbing processes, ensuring some resilience to the ecosystem (Frontier, 1977; Frontier \& Pichod-Viale, 1990).

\section{Adaptation to volume variations}

When no major water input was noted, organism densities per volume unit were mainly controlled by production, predation and sedimentation. A water input induced a dilution and a decrease of abundances expressed per volume unit. According to the volume increase (difference between $V_{t+1}$ and $V_{t}$ ) observed between two consecutive samples at $t$ and $t+1$, it was possible to calculate the theoretical density $S$ at $t+1$ from the hypothesis of a stock conservation between $S_{t}$ and $S_{t+1}$. From comparisons between this theoretical density $\left(S_{t} \times V_{t} / V_{t+1}\right)$ and the observed values $\left(S_{t+1}\right)$, it is possible to conclude that there was:

- a dilution in the case of equality,

- a stimulation of production in the case of a positive gap,

- a disappearance (lysis, predation, sedimentation) greater than the production in the case of a negative gap.

The time series of the difference $D$ between theoretical and observed bacterial and phytoplankton densities are represented in Fig. 7. These two groups were chosen because they are characterized by high growth rates, allowing significant variations of abundance to occur within the sampling interval. In order to compare the two time series, the series were centered and reduced. The $D$-index for bacteria showed large variations at the beginning of the proliferation phase (D1D3), with a nocturnal production exceeding the losses and an equilibrated diurnal production. These variations were linked to the fluctuations of climatic conditions enforced by a very low water level. Afterwards, the presence of predators (flagellates, then ciliates) might explain the drastic decrease of bacterial densities. From that step followed a sequence characterized by bacterial communities showing productions roughly equivalent to losses. The sudden variation of pond volume due to rainfall was compensated immediately by new production with a delay close to $12 \mathrm{~h}$. The $D$ index for the chlorophyll biomass showed diel successions characterized by diurnal increases and nocturnal losses. Between D4 and D5, the productions observed during the diurnal phases were higher than the losses due to the combined effects of sedimentation and grazing by protozoans. During the concomitant nocturnal 

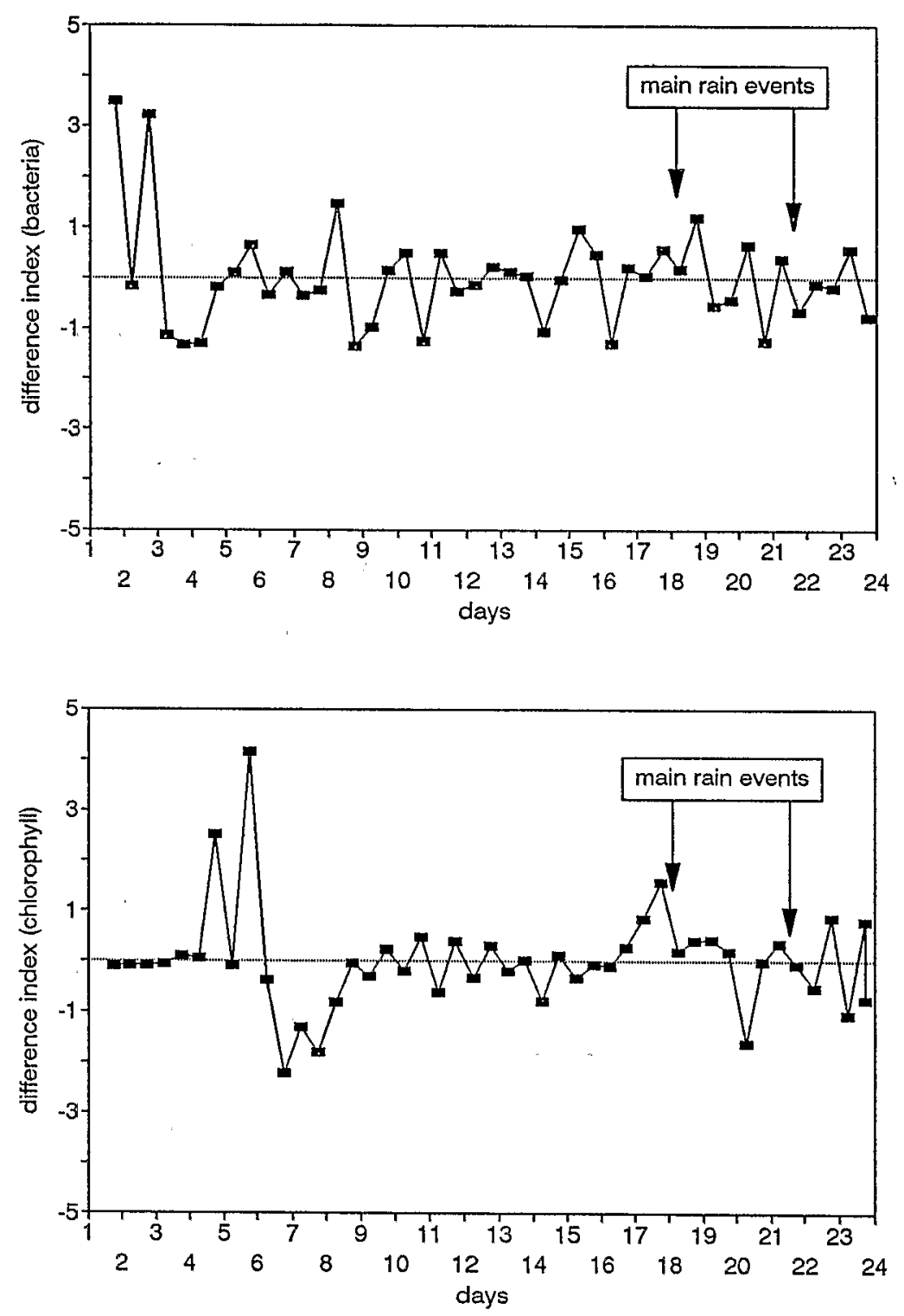

Fig. 7. Time series of the $D$-index for bacterial and chlorophyll biomasses.

phases, the increase in biomass compensated approximately the loss. This process was observed neither from D6, with the sudden diurnal decrease of mineral nitrogen concentrations linked to the algal uptake, nor afterwards, due to the successive developments of flagellates, ciliates and rotifers (B. plicatilis). Thus, the index variations reflected the phytoplanktonic biomass stabilization on a $24 \mathrm{~h}$ scale, and diurnal algal productions compensated the daily losses due to sedimentation and grazing. During the second algal bloom, diurnal as well as nocturnal productions exceeded the losses. This algal proliferation was suddenly stopped by the first storm, which induced a drastic change of chemical (nutrients, $\mathrm{pH}$ and conductivity) and physical (light attenuation due to turbidity) conditions in the pond. On the contrary to bacterial communities, phytoplankton did not compensated immediately the volume increase (therefore colonization space) by new production. The fit of chlorophyll biomass was then completed through alternations of exceeding diurnal productions and nocturnal losses. These losses would result from decreasing photosynthetic activities and/or from increasing grazing activities. 


\section{Conclusion}

During a recolonization sequence in a tropical pond and due to the initial conditions (great amount of easily degradable organic compounds) following the liming process, heterotrophic communities (bacteria) developed before the phytoplanktonic bloom. Development of heterotrophic and autotrophic communities was first carried out by growth of organisms in nonlimited nutrient conditions. This close link with the resource induced a rapid elimination of the opportunist species as soon as the nutrients were depleted owing to their overconsumption. This biological succession was based on a catastrophic-type system, successively controlled by 'bottom-up' factors during proliferation phase and 'top-down' factors during species collapse. Therefore, any water input inducing a new supply of nutrients could give the opportunity to other species to develop and could produce a stimulation of production. Besides this quantitative aspect, the selection of the colonizing species was established in accordance with their nutrient requirement and tolerance. The system transformation was completed with the development of consumers controlled through a predator-prey equilibrium. The development of these organisms was more or less independent of environmental conditions, and the success of their installation was directly related to the existence of a nutritive resource. Their proliferation was thus only possible within a narrow ecological window, characterized by the temporal concordance of abundantly available food and the lack of control by predators. The opening of such a window was particularly limited in time because these organisms have high metabolic rates and high food requirements.

\section{Acknowledgments}

We thank N. Kaba for help in improving the English.

\section{References}

Adams, J., 1985. The identification and interpretation of guild structures in ecological communities. J. anim. Ecol. 54: 43-59.

Aminot, A. \& M. Chaussepied, 1983. Manuel des analyses chimiques en milieu marin. CNEXO, BNDO/Documentation, Paris, $395 \mathrm{pp}$.

Arce, R. G. \& C. E. Boyd, 1975. Effects of agricultural limestone on water chemistry phytoplankton productivity and fish production in soft water ponds. Trans. am. Fish Soc. 104: 308-312.
Arf, R, D. Guiral \& J. P. Torréton, 1991. Natural recolonization of a tropical pond: day to day variations in the photosynthetic parameters. Aquat. Sci. 53: 39-54.

Beaver, J. R. \& T. L. Crisman, 1989. The role of ciliated protozoa in pelagic freshwater ecosystems. Microb. Ecol. 17: 111-136.

Bernard, C. \& F. Razzoulzadegan, 1990. Bacteria or microflagellates as a major food source for marine ciliates: possible implications for the microzooplankton. Mar. Ecol, Prog. Ser. 64: 147-155.

Bonou, C., 1990. Etude de la productivité planctonique dans des étangs d'aquaculture en milieu saumâtre tropical. Thesis INP Toulouse, $220 \mathrm{pp}$.

Borsheim, K. Y. \& G. Bratbak, 1987. Cell volume to cell carbon conversion factors for a bacterivorous Monas sp. enriched from sea water. Mar. Ecol. Prog. Ser. 36: 171-175.

Clément, E., 1916. Plant succession: an analysis of the development of vegetation. Publ. Carneg. Inst. 242.

Connell, J. H. \& R. O. Stayler, 1977. Mechanisms of succession in natural communities and their role in community stability and organization. Am. Nat. 111:1119-1144.

De Jonge, V. N. \& L. A. Bowman, 1977. A simple density separation for quantitative isolation of meiobenthos using the colloidal silica Ludox TM . Mar. Biol. 42: 143-148.

Delincé, G., 1992. The ecology of the fish pond ecosystem, with special reference to Africa. Developments in Hydrobiology 72 , $230 \mathrm{pp}$.

Frontier, S., 1977. Réflections sur une thérie des écosystèmes. Bull. Ecol. 8: 445-464.

Frontier, S. \& D. Pichod-Viale, 1990. Ecosystèmes. Structure, fonctionnement, évolution. Masson, Paris, 392 pp.

Hem, S., M. Legendre, L. Trebaol, A. Cisse \& Y. Moreau, 1994. Recherches sur les principales espèces d'intérêt aquacole en milieu lagunaire. In J. R. Durand, P. Dufour, D. Guiral \& S. G. Zabi (eds), Environnement et ressources aquatique de Côte d'Ivoire, 2 Le milieu lagunaire. Editions de l'ORSTOM, Paris, in press.

Hunt, D. \& C. E. Boyd, 1981. Alkalinity losses from ammonium fertilizers used in fish ponds. Trans. am. fish. Soc. 110: 81-85.

Keller, A. A. \& U. Riebesel, 1989. Phytoplankton carbon dynamics during a winter-spring diatom bloom in an enclosed marine ecosystem: primary production, biomass and loss rates. Mar. Biol. 103: 131-142.

Legendre, M., M. Pagano \& L. Saint-Jean, 1987. Peuplements et biomasse zooplanctonique dans des étangs de pisciculture lagunaire (Layo, Côte d'Ivoire). Etude de la recolonisation après la mise en eau. Aquaculture 67: 32I-341.

McCormick, P. V., E. P. Smith \& J. Cairns, 1991. The relative importance of population versus community processes in microbial primary succession. Hydrobiologia 213: 83-98.

Nagata, T. \& Y. Watanabe, 1990. Carbon and nitrogen to volume ratio of bacterioplankton grown under different nutritional conditions. Appl, envir. Microbiol. 56: 1303-1309.

Porter, K. G. \& Y.S. Feig, 1980. The use of DAPI for identifying and counting aquatic microflora. Limnol. Oceanogr. 25: 943-948.

Pourriot, R, 1977. Food and feeding habitats of the Rotifera. Arch. Hydrobiol. Beih. Ergebn. Limnol. 8: 243-260.

Riemann, B. \& M. Sondergaard, 1984. Measurement of diel rates of bacterial secondary production in aquatic environments. Appl. Environ. Microbiol. 47: 632-638.

Sanders, R. W., K. G. Porter, S. J. Benett \& A. E. DeBiase, 1989. Seasonal patterns of bacterivory by flagellates, ciliates, rotifers and cladocerans in a freshwater planktonic community. Limnol. Oceanogr. 32: 673-687. 
Sherr, E. B. \& B. F. Sherr, 1987. Bacterivory in pelagic ciliated protozoa. Nature 325: 710.

Sherr, E. B., B. F. Sherr \& J. McDaniel, 1991. Clearance rates of $<6 \mu \mathrm{m}$ fluorescently labeled algae (FLA) by estuarine protozoa: potential grazing impact of flagellates and ciliates. Mar. Ecol. Prog. Ser. 68: 81-92.

Simon, M. \& F. Azam, 1989. Protein content and protein synthesis rates of planktonic marine bacteria. Mar. Ecol. Prog. Ser. 51: 203-213.

Smith, S. V. \& J. T. Hollibaugh, 1989. Carbon-controlled nitrogen cycling in a marine 'macrocosm'; an ecosystem-scale model for managing cultural eutrophication. Mar. Ecol. Prog. Ser. 52: 103109.
Strickland, J. D. H. \& T. R. Parsons, 1972. A practical handbook of seawater analysis. Fish. Res. Board Can. 167, 311 pp.

Turley, C. M., R. C. Newell \& D. B. Robins, 1986. Survival strategies of two small marine ciliates and their role in regulating bacterial community structure under experimental conditions. Mar. Ecol. Prog. Ser, 33: 59-70.

Utermöhl, H., 1958. Zur Vervollkommnung der quantitativen Phytoplankton-Methodik. Mitt. int. Ver. Limnol. 9: 1-38.

Yentsch, C. S. \& D. W. Menzel, 1963. A method for the determination of phytoplankton chlorophyll and phaeophytin by fluorescence. Deep Sea Res. 10: 221-231. 